Litteratur

1. Toft H. Er pårørenderollen for omfattende? Tidsskr Nor Legeforen 2013; 133: 1294

Dette er en redigert versjon av et innlegg publisert som rask respons på nett 13.6. 2013. http://tidsskriftet.no/article/3027008/

\section{Pårørendes rett til å medvirke}

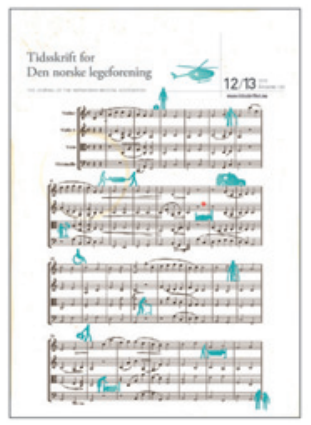

Er pårørenderollen for omfattende? spør Håkon Toft i Tidsskriftet nr. 12-13/2013 (1) . At pårørende skal ha rett til å medvirke i pasientens behandling og omsorg, er like selvsagt som det kan være vanskelig. Utgangspunktet må være kommunikasjon og samarbeid. Målet er at pasienten skal få den beste behandling og da er det helt naturlig at pårørende og lege snakker sammen om hva dette innebærer, hvilke behandlingsalternativer man har og hva som vil være tjenlig for pasienten. Sykepleiere og annet helsepersonell som er involvert i pasientens behandling, bør også være en del av slike samtaler. Det betyr ikke at pårørende har vetorett $\mathrm{i}$ forhold til medisinsk behandling, men at de skal informeres og rådføres.

Dette er det prinsipielle. Så kan det være situasjoner som er vanskelige, eller der pårørende i liten grad kan eller vil samhandle eller er kompetente til det. Men det kan også være motsatte situasjoner, der pårørende er en stor ressurs i samhandling om pasientens beste, er meget kunnskapsrike, oppdaterte og ønsker delaktighet i beslutninger.

Gjensidighet, åpenhet og informasjon bør være idealet. Det er uansett galt å generalisere fra enkeltsituasjoner i så kompliserte og sammensatte problemstillinger som dette.

\section{Per Nortvedt}

p.nortvedt@medisin.uio.no

Per Nortvedt (f. 1952) er anestesisykepleier, dr.polit. og professor ved Senter for medisinsk etikk, Universitetet i Oslo.

Ingen oppgitte interessekonflikter.

\section{Litteratur}

1. Toft H. Er pårørenderollen for omfattende? Tidsskr Nor Legeforen 2013; 133: 1294

Dette er en redigert versjon av et innlegg publisert som rask respons på nett 26.6. 2013. http://tidsskriftet.no/article/3027008/

\section{Pårørenderollen}

Er pårørenderollen for omfattende? spør Håkon Toft i en kommentarartikkel i Tidsskriftet nr. 12-13/2013 (1). Med referanse til en sak som ble omtalt i mediene, der pårørende ikke var tatt med på råd om hvilke medikamenter pasienten skulle ha, synes Toft å trekke den slutning at pårørende i den konkrete saken skulle ha bestemt medisineringen. Han synes videre å forutsette at pårørende gjennom helsepersonelloven og pasient- og brukerrettighetsloven er gitt et generelt behandlingsansvar.

Han hevder også at ett av målene med helsepersonelloven var «å rive legen ned fra pidestallen». Det er ukjent for undertegnede, som hadde en sentral rolle ved utformingen av helsepersonelloven. Lovens formål var derimot å tydeliggjøre ansvaret for alt helsepersonell, uavhengig av profesjonstilhørighet. Profesjonspliktene som er nedfelt i helsepersonelloven skal bl.a. ivareta pasienters sikkerhet, uten hensyn til hvem som yter helsehjelpen.Verken pasienten eller pårørende skal avgjøre hvilken medisinsk behandling en pasient skal ha. Legen har, nå som før, det hele og fulle ansvaret for pasientbehandlingen. En rett til å bli informert, hørt og tatt med på råd er ikke det samme som et behandlingsansvar. Pårørendes rett til å medvirke i tilfeller der pasienten av ulike grunner er ute av stand til å ivareta egne interesser er avledet av pasientens egen medvirkningsrett. Denne følger av pasient- og brukerrettighetsloven $\S 3-1$. I denne bestemmelsen heter det at pasienten har rett til å medvirke ved gjennomføring av helsehjelpen og kan velge mellom tilgjengelige og forsvarlige undersøkelsesog behandlingsmetoder. Hva som er forsvarlig, beror på et medisinsk skjønn og bestemmes av legen. Retten til å medvirke fritar med andre ord ikke legen fra å treffe avgjørelser som sikrer forsvarlig helsehjelp til pasienten. Medvirkningen fører heller ikke til at pasienten eller dennes pårørende blir ansvarlig for behandlingen.

Parallellen som forfatteren trekker mellom pårørendes rolle og det hevdvunne prinsippet om at legen ikke skal behandle sine egne er således lite treffende.

Men god kommunikasjon mellom behandlingspersonell og pasienter og deres pårørende er ment å gi grunnlag for god behandling og antas i de fleste tilfeller å fungere i samsvar med formålet.

\section{Bente Ohnstad}

bente.ohnstad@hil.no

Bente Ohnstad (f. 1953) er jurist, pedagog og rektor ved Høgskolen i Lillehammer.

Ingen oppgitte interessekonflikter.

Litteratur

1. Toft H. Er pårørenderollen for omfattende? Tidsskr Nor Legeforen 2013; 133 1294.

Dette er en redigert versjon av et innlegg publisert som rask respons på nett 5.7. 2013. http://tidsskriftet.no/article/3027008/

\section{Profesjonalitet}

I Tidsskriftet nr. 12-13/2013 sto en fin artikkel av Ingrid Neteland (1). Jeg tror hun har helt rett, det er det å se pasienten som er å være profesjonell. Jeg har en nær pårørende som har vært ut og inn av sykehus de siste årene, og hun er faktisk ekstremt fornøyd med helsevesenet og den behandlingen hun har fått, og hun har vært på utallige avdelinger og med en komplisert og mangfoldig sykehistorie. Det eneste det av og til skorter på er informasjon, å få besvart spørsmål, et sted der medisinske ord og uttrykk kan forklares, der målte verdier av for eksempel blodprøver blir satt i perspektiv osv.

Men hun er heldig, hun er med på et langvarig forsknings- og oppfølgingsprosjekt, og den ansvarlige legen der er den som står for informasjonen. Så hun får dekket informasjonsbehovet sitt, i alle fall på sikt. Det er selvsagt heller ikke sånn at hun ikke får noe informasjon, men det er alltid noe som står igjen ubesvart eller uklart osv. Primærlegen har for lengst gitt opp å følge med i alt som skjer med henne.

Jeg vet nesten ingenting om hvordan helsevesenet fungerer organisatorisk, eller hvordan ansvar fordeles osv. Løsningen synes likevel enkel: Alle pasienter får tildelt en ansvarlig kontaktperson, en liaison-offiser, som ivaretar informasjonsbehovet, både under innleggelse og etter at pasienten har kommet hjem. Pasienten må ha en person, ikke et kontor, å forholde seg til.

\section{Line Varskog}

line.varskog@gmail.com

Line Varskog (f. 1965) er gestaltterapeut MNGF og driver egen praksis. Ingen oppgitte interessekonflikter.

\section{Litteratur}

1. Neteland I. Hvor er du? Tidsskr Nor Legeforen 2013; 133: 1340-1.

Dette er en redigert versjon av et innlegg publisert som rask respons på nett 15.06.2013. http://tidsskriftet.no/article/3029493/ 